\title{
EFEKTIVITAS EKSTRAK ETANOL DAUN KIRINYUH (CHROMOLAENA ODORATA L) SEBAGAI ANTIBAKTERI SALMONELLA TYPHI DAN STAPHYLOCOCCUS AUREUS
}

\author{
Fadia $^{1}$, Nurlailah ${ }^{2}$, Tini Elyn Herlina ${ }^{3}$, Leka Lutpiatina ${ }^{4}$ \\ 1,2,3,4 Teknologi Laboratorium Medik Poltekkes Kemenkes Banjarmasin. \\ Email korespondensi: nurlailah28@ gmail.com
}

\begin{abstract}
ABSTRAK
Salmonella typhi dan Staphylococcus aureus merupakan bakteri patogen penyebab timbulnya penyakit infeksi. Pengobatan penyakit tersebut dapat dilakukan dengan pemberian obat antibakteri. Salah satu tumbuhan yang memiliki potensi untuk digunakan sebagai obat antibakteri yaitu daun kirinyuh karena adanya kandungan senyawa kimia seperti flavonoid, tanin dan saponin yang berpotensi sebagai antibakteri. Penelitian ini bertujuan untuk mengetahui Konsentrasi Hambat Minimal (KHM) dan Konsentrasi Bunuh Minimal (KBM) ekstrak etanol daun kirinyuh terhadap pertumbuhan Salmonella typhi dan Staphylococcus aureus. Penelitian ini merupakan tahap awal pengembangan obat herbal untuk mengobati infeksi Salmonella typhi dan Staphylococcus aureus. Penelitian terdiri atas 5 perlakuan yaitu konsentrasi 20\%, 40\%, $60 \%$, $80 \%$ dan $100 \%$ ekstrak etanol daun kirinyuh dengan 5 pengulangan. Uji aktivitas antibakteri dilakukan dengan metode KHM dan KBM. Bahan penelitian menggunakan daun dari Chromolaena odorata L. di daerah Sungai Besar, Banjarbaru Selatan, Kalimantan selatan, Indonesia. Hasil penelitian menunjukkan bahwa hasil rata-rata KHM ekstrak etanol daun kirinyuh terhadap Salmonella typhi: 20\% dan Staphylococcus aureus: $20 \%$. Sedangkan hasil rata-rata nilai KBM terhadap Salmonella typhi: $40 \%$ dan Staphylococcus aureus: 40\%. Berdasarkan hasil yang diperoleh dapat disimpulkan bahwa ekstrak etanol daun kirinyuh mempunyai daya hambat terhadap pertumbuhan Salmonella typhi dan Staphylococcus aureus. Ekstrak etanol daun kirinyuh berpotensi sebagai obat herbal untuk infeksi bakteri namun memerlukan penelitian lebih lanjut untuk mengetahui pengaruhnya secara in vivo.
\end{abstract}

Kata kunci : Efektifitas; Chromolaena odorata L.; antibakteri; Salmonella typhi; Staphylococcus aureus 


\title{
EFFECTIVENESS OF KIRINYUH LEAF (CHROMOLAENA ODORATA L) ETHANOL EXTRACT AS AN ANTIBACTERIAL OF SALMONELLA TYPHI AND STAPHYLOCOCCUS AUREUS
}

\begin{abstract}
Salmonella typhi and Staphylococcus aureus are pathogenic bacteria that cause infectious diseases. Treatment of these diseases can be done by giving antibacterial drugs. One of the plants that can be used as an antibacterial drug is the leaves of Chromolaena odorata $L$. due to the presence of chemical compounds such as flavonoids, tannins, and saponins that have the potential as antibacterial. This study aims to determine the Minimum Inhibitory Concentration (MIC), and Minimum Bactericidal Concentration (MBC) ethanol extract of Chromolaena odorata L. leaves on the growth of Salmonella typhi and Staphylococcus aureus. This research is the initial stage of the development of herbal medicines to treat Salmonella typhi and Staphylococcus aureus infections. The study consisted of 5 treatments, namely concentrations of 20\%, 40\%, 60\%, 80\%, and 100\% ethanol extract of Chromolaena odorata L. leaves with five repetitions. The antibacterial activity test was carried out by MIC and MBC methods. The research material uses leaves from Chromolaena odorata L. in the Sungai Besar area, Banjarbaru, South Kalimantan, Indonesia. The results showed that the average MIC yield of ethanol extract of Chromolaena odorata L. leaves against Salmonella typhi: 20\% and Staphylococcus aureus: 20\%. While the average yield of MBC values against Salmonella typhi: $40 \%$ and Staphylococcus aureus: $40 \%$. Based on the results obtained, it can be concluded that the ethanol extract of Chromolaena odorata L. leaves has an inhibitory effect on the growth of Salmonella typhi and Staphylococcus aureus. Chromolaena odorata L. leaves has potential as herbal medicine against bacterial infections but requires further research to determine its effect in vivo.
\end{abstract}

Keywords: Effectiveness; Chromolaena odorata L.; antibacterial; Salmonella typhi; Staphylococcus aureus

\section{PENDAHULUAN}

Penyakit infeksi merupakan salah satu penyebab utama terjadinya gangguan kesehatan di negara berkembang, termasuk Indonesia. Penyakit infeksi yang disebabkan oleh tuberculosis (Rifa'i, A, 2019) dan Staphylococcus aureus menjadi kendala utama di Indonesia, disamping masalah bakteri kontaminasi lingkungan seperti Staphylococcus aureus (Mustika Sari, P, 2019) dan Bacillus (Fahani, A., 2019). Menurut Wulandari (2014), ada sekitar 50 spesies bakteri yang bersifat patogenik atau mampu menimbulkan penyakit. Beberapa contoh bakteri gram 
negatif dan gram positif yang dapat menyebabkan infeksi diantaranya adalah Salmonella typhi dan Staphylococcus aureus.

Salmonella typhi merupakan bakteri penyebab penyakit demam tifoid. Bakteri ini termasuk gram negatif berbentuk batang, bersifat motil dan memiliki kemampuan untuk menginfeksi manusia jika tertelan (Yusliana, 2019). Berdasarkan data World Health Organization (WHO) diketahui bahwa penyakit demam tifoid di dunia mencapai 11-21 juta kasus per tahun yang mengakibatkan sekitar 128.000-161.000 kematian setiap tahunnya (WHO, 2018).

Staphylococcus aureus adalah salah satu bakteri gram positif berbentuk bulat dan bersifat patogen bagi manusia. Bakteri ini dapat menginfeksi setiap jaringan pada tubuh dan menyebabkan timbulnya penyakit dengan tanda khas berupa peradangan, nekrosis, dan pembentukan abses. Infeksi Staphylococcus aureus dapat berasal dari kontaminasi langsung dari luka, misalnya infeksi pasca operasi (Laia dkk, 2019).

Pengobatan penyakit infeksi pada umumnya menggunakan obat antibiotik. Namun, penggunaan antibiotik secara berlebihan dapat menimbulkan risiko seperti resistensi bakteri. Selain itu, penggunaan antibiotik juga sering menyebabkan efek samping seperti reaksi alergi, reaksi toksik, serta perubahan biologis dan metabolis pada hospes (Tanu, 2012). Hal tersebut membuat kecenderungan masyarakat untuk memilih obat-obatan dari bahan alami seperti tumbuhan-tumbuhan yang terdapat disekitar untuk digunakan sebagai obat tradisional karena mudah diperoleh serta memiliki efek samping yang minim.

Salah satu tumbuhan yang dapat dimanfaatkan sebagai obat antibakteri adalah daun kirinyuh. Daun kirinyuh (Chromolaena odorata L) memiliki senyawa kimia yang berpotensi memiliki sifat antibakteri seperti flavonoid, tanin, dan saponin (Hidayatullah, 2018). Secara tradisional daun ( telah digunakan sebagai obat dalam penyembuhan luka untuk mengobati radang tenggorokan, obat malaria, sakit kepala, antidiare, dan astringent antiplasmodial, antihipertensi dan anti inflamasi (Vaisakh dan Pandey, 2012).

Aktivitas suatu antibakteri dapat diketahui dengan menentukan daya hambat dan daya bunuhnya terhadap pertumbuhan bakteri menggunakan metode difusi dan dilusi. Berdasarkan penelitian Rahayu (2017) diketahui bahwa ekstrak etanol daun kirinyuh konsentrasi $90 \%$ menggunakan metode difusi berpotensi kuat menghambat pertumbuhan Staphylococcus aureus dengan rata-rata diameter zona hambat $11,1 \mathrm{~mm}$ dan berpotensi sedang menghambat pertumbuhan bakteri Escherichia coli dan Pseudomonas aeruginosa dengan rata-rata diameter zona hambat masing-masing 7,93 dan 9,6 mm.

Penelitian lain yang dilakukan oleh Yutika dkk., (2015) diketahui bahwa ekstrak daun kirinyuh konsentrasi 30\% menggunakan metode difusi (Kirby bauer) dapat menghambat bakteri gangren dengan kategori sedang. 
Hasil penelitian Priono dkk., (2016), menunjukkan hasil bahwa ekstrak daun kirinyuh menggunakan metode difusi (sumuran) mempunyai efektivitas penghambatan yang lebih baik dibandingkan dengan ekstrak daun kelor (M. oleifera Lamck.) terhadap pertumbuhan Escherichia coli dan Staphylococcus aureus.

Berdasarkan penelitian terdahulu telah diketahui bahwa daun kirinyuh. memiliki daya hambat terhadap pertumbuhan beberapa bakteri dengan menggunakan metode difusi. Namun, penelitian terkait uji aktivitas antibakteri ekstrak daun kirinyuh dengan metode dilusi untuk melihat daya hambat dan daya bunuhnya terhadap Salmonella typhi dan Staphylococcus aureus belum banyak dilakukan. Tujuan penelitian ini adalah untuk mengetahui Konsentrasi Hambat Minimal (KHM) dan Konsentrasi Bunuh Minimal (KBM) ekstrak etanol daun kirinyuh terhadap pertumbuhan Salmonella typhi dan Staphylococcus aureus.

\section{METODE PENELITIAN}

Penelitian bersifat eksperimen dengan rancangan Posttest Only Control Group Design yaitu dengan melakukan pemeriksaan KHM dan KBM ekstrak etanol daun kirinyuh pada konsentrasi $20 \%, 40 \%, 60 \%, 80 \%$ dan $100 \%$ terhadap pertumbuhan Salmonella typhi dan Staphylococcus aureus. Kemudian dibandingkan dengan kelompok kontrol negative (larutan TSB), kontrol positif (kloramphenikol) dan kontrol ekstrak etanol daun kirinyuh.

\section{Bahan penelitian}

Bahan penelitian adalah daun dari Chromolaena odorata $L$. yang ada di daerah Sungai Besar, Banjarbaru Selatan, Indonesia. Bagian daun yang digunakan adalah daun tua dan muda yang utuh, segar, tidak ada bagian yang busuk dan bersih dari hama.

\section{Variabel penelitian}

Variabel bebas dalam penelitian ini adalah konsentrasi ekstrak etanol daun kirinyuh yaitu 20\%, 40\%, 60\%, $80 \%$ dan $100 \%$. Variabel terikat dalam penelitian ini adalah pertumbuhan Salmonella typhi dan Staphylococcus aureus berdasarkan penentuan Konsentrasi Hambat Minimal (KHM) dan Konsentrasi Bunuh Minimal (KBM).

\section{Pembuatan ekstrak daun kirinyuh}

Daun kirinyuh sebanyak 800 gram dicuci dengan air mengalir kemudian keringkan selama \pm 2 minggu. Daun dijadikan serbuk dengan ayakan mesh 60. Proses maserasi daun Chromolaena ododrata L. dengan etanol 96\% (1:4) selama 3 hari. Maserat dipekatkan menggunakan rotary evaporator pada suhu $55^{\circ} \mathrm{C}$ hingga diperoleh ekstrak kental. Ekstrak kental kemudian dilarutkan dengan aqua dest steril perbandingan 2:1 sehingga diperoleh konsentrasi 200\%. Pembuatan konsentrasi 160\%, 120\%, 80\%, 40\% menggunakan larutan konsentrasi 200\% dan aqua dest. Suspensi Salmonella typhi dan Staphylococcus aureus adalah hasil inkubasi bakteri selama 24 jam pada suhu $37^{\circ} \mathrm{C}$. 


\section{Uji fitokimia}

Dilakukan uji fitokimia secara kualitatif untuk mengetahui kandungan metabolit sekunder dalam ekstrak daun kirinyuh. Skrining fitokimia yang dilakukan meliputi pemeriksaan uji alkaloid, flavonoid, tannin dan saponin.

\section{Uji KHM dan uji KBM}

Uji KHM dilakukan dengan mencampurkan $1 \mathrm{~mL}$ ekstrak etanol daun Chromolaena ododrata L. dan 1 $\mathrm{mL}$ suspensi bakteri dengan pengulangan 3 kali. Konsentrasi akhir larutan uji setelah ditambah suspensi bakteri adalah setengah dari konsentrasi awal sehingga konsentrasi larutan uji menjadi $100 \%$, 80\%, 60\%, 40\%, $20 \%$. Hasil KHM setelah Inkubasi 24 jam suhu $37^{\circ} \mathrm{C}$ ditentukan pada larutan yang mengandung kadar ekstrak terendah tetapi masih mampu menghambat bakteri ditandai dengan larutan jernih. Dari larutan yang menunjukkan KHM diambil 20 ul sebarkan pada permukaan media Nutrient Agar plate inkubasi 24 jam suhu $37^{\circ} \mathrm{C}$. KBM ditunjukkan dengan media Nutrient Agar plate yang tidak ada pertumbuhan koloni bakteri.

\section{HASIL DAN PEMBAHASAN}

Konsentrasi Hambat Minimal
(KHM) Salmonella typhi dan
Staphylococcus aureus

Berdasarkan hasil pengujian antibakteri ekstrak etanol daun kirinyuh terhadap pertumbuhan Salmonella typhi dan Staphylococcus aureus memperlihatkan kejernihan pada setiap konsentrasi yaitu konsentrasi 20\%, $40 \%, 60 \%$, 80\% dan 100\%. Kontrol negatif menunjukkan hasil larutan keruh, sedangkan kontrol positif larutan jernih. Sehingga hasil KHM untuk Salmonella typhi berada pada konsentrasi $20 \%$, begitu pula KHM untuk Staphylococcus aureus berada pada konsentrasi $20 \%$.

\section{Konsentrasi Bunuh Minimal (KBM) Salmonella typhi dan Staphylococcus aureus}

Berdasarkan penentuan

Konsentrasi Bunuh Minimal (KBM) terhadap Salmonella typhi dan Staphylococcus aureus diperoleh adanya pertumbuhan koloni pada konsentrasi 20\% dengan jumlah 1-2 koloni. Hal tersebut menunjukkan bahwa pada konsentrasi tersebut ekstrak etanol daun kirinyuh belum bisa membunuh sedangkan pada konsentrasi 40\%-100\% tidak terjadi pertumbuhan koloni yang menandakan pada konsentrasi tersebut ekstrak sudah dapat membunuh Salmonella typhi dan Staphylococcus aureus. Untuk lebih jelasnya, hasil penentuan Konsentrasi Bunuh Minimal (KBM) terhadap Salmonella typhi dan Staphylococcus aureus dapat dilihat pada tabel 3 dan 4 sebagai berikut.

Tabel 1. Hasil Konsentrasi Bunuh Minimal (KBM) Ekstrak Etanol Daun kirinyuh terhadap Pertumbuhan Salmonella typhi

\begin{tabular}{|c|c|c|c|c|c|c|c|c|}
\hline \multirow{2}{*}{$\begin{array}{l}\text { Pengulang } \\
\text { an Ke- }\end{array}$} & \multicolumn{5}{|c|}{ Jumlah Koloni Bakteri Pada Konsentrasi } & \multicolumn{3}{|c|}{ Kontrol } \\
\hline & $20 \%$ & $40 \%$ & $60 \%$ & $80 \%$ & $100 \%$ & Negatif & Positif & Ekstrak \\
\hline
\end{tabular}




\begin{tabular}{ccccccccc}
\hline 1 & 1 & 0 & 0 & 0 & 0 & $\infty$ & 0 & 0 \\
2 & 0 & 0 & 0 & 0 & 0 & $\infty$ & 0 & 0 \\
3 & 0 & 0 & 0 & 0 & 0 & $\infty$ & 0 & 0 \\
4 & 1 & 0 & 0 & 0 & 0 & $\infty$ & 0 & 0 \\
5 & 1 & 0 & 0 & 0 & 0 & $\infty$ & 0 & 0 \\
Rata-Rata & 1 & 0 & 0 & 0 & 0 & $\infty$ & 0 & 0 \\
\hline
\end{tabular}

Tabel 2. Hasil Konsentrasi Bunuh Minimal (KBM) Ekstrak Etanol Daun kirinyuh (Chromolaena odorata L.) terhadap Pertumbuhan Staphylococcus aureus

\begin{tabular}{ccccccccc}
\hline \multirow{2}{*}{$\begin{array}{c}\text { Pengulang } \\
\text { an Ke- }\end{array}$} & \multicolumn{4}{c}{$\begin{array}{c}\text { Ekmlah Koloni Bakteri Pada Konsentrasi } \\
\text { Ekstrak Etan Daun kirinyuh }\end{array}$} & \multicolumn{3}{c}{ Kontrol } \\
\hline 1 & $20 \%$ & $40 \%$ & $60 \%$ & $80 \%$ & $100 \%$ & Negatif & Positif & Ekstrak \\
2 & 1 & 0 & 0 & 0 & 0 & $\infty$ & 0 & 0 \\
3 & 2 & 0 & 0 & 0 & 0 & $\infty$ & 0 & 0 \\
4 & 0 & 0 & 0 & 0 & 0 & $\infty$ & 0 & 0 \\
5 & 1 & 0 & 0 & 0 & 0 & $\infty$ & 0 & 0 \\
Rata-rata & 0 & 0 & 0 & 0 & 0 & $\infty$ & 0 & 0 \\
\hline
\end{tabular}

Keterangan :

$\infty=$ Jumlah koloni tak terhingga

Pada tabel 1 dan 2 memperlihatkan hasil bahwa perlakuan dengan konsentrasi 40\%, 60\%, 80\% dan $100 \%$ yang telah dilakukan pengulangan sebanyak 5 kali mampu membunuh pertumbuhan bakteri karena tidak ditemukan adanya koloni bakteri yang tumbuh baik Salmonella typhi maupun Staphylococcus aureus. Sehingga Konsentrasi Bunuh Minimal (KBM) ekstrak etanol daun kirinyuh. terhadap Salmonella typhi maupun Staphylococcus aureus masing-masing pada konsentrasi $40 \%$.

\section{Hasil Uji Fitokimia Daun Kirinyuh (Chromolaena odorata L.)}

Berdasarkan uji fitokimia yang telah dilakukan di laboratorium FMIPA secara kualitatif didapatkan hasil bahwa daun kirinyuh (Chromolaena odorata L.) positif mengandung beberapa senyawa aktif yang dapat digunakan sebagai antibakteri. Hasil uji fitokimia daun kirinyuh (Chromolaena odorata L.) dapat dilihat pada tabel 5 sebagai berikut.

Tabel 3. Hasil Uji Fitokimia Daun kirinyuh (Chromolaena odorata L.)

\begin{tabular}{cllc}
\hline \multicolumn{1}{c}{ Parameter } & \multicolumn{1}{c}{ Pereaksi } & \multicolumn{1}{c}{ Hasil } & Kesimpulan \\
\hline Alkaloid & Dragendorff & Endapan jingga & Positif \\
Flavonoid & HCI pekat dan Mg & $\begin{array}{l}\text { Warna merah atau } \\
\text { jingga }\end{array}$ & Positif \\
& & & \\
\hline
\end{tabular}




\begin{tabular}{llll}
\hline Saponin & Aquades & Terbentuk busa & Positif \\
Steroid & $\begin{array}{l}\mathrm{CH}_{3} \mathrm{COOH} \text { glasial } \\
\text { dan } \mathrm{H}_{2} \mathrm{SO}_{4} \text { pekat }\end{array}$ & Warna biru & Positif \\
Triterpenoid & $\begin{array}{l}\mathrm{CH}_{3} \mathrm{COOH} \text { glasial } \\
\text { dan } \mathrm{H}_{2} \mathrm{SO}_{4} \text { pekat }\end{array}$ & Warna merah & Positif \\
Tanin & $\mathrm{FeCl}_{3} 10 \%$ & Warna biru tua & Positif \\
\hline
\end{tabular}

Berdasarkan penelitian yang telah dilakukan daun kirinyuh efektif sebagai antibakteri terhadap pertumbuhan Salmonella typhi dan Staphylococcus aureus, merujuk dari hasil KBM ditabel 3 dan 4, yaitu pada konsentrasi $40 \%$.

Hal ini sesuai dengan penelitian Priono dkk (2016) tentang efektivitas antibakteri daun kirinyuh menggunakan metode difusi diperoleh hasil bahwa konsentrasi terbaik daun kirinyuh dalam menghambat pertumbuhan Staphylococcus aureus adalah pada konsentrasi $50 \%$ dengan zona hambat sebesar 10,41 mm.

Berbeda dengan penelitian Rahayu (2017), konsentrasi ekstrak daun kirinyuh lebih tinggi dalam menghambat pertumbuhan Staphylococcus aureus pada konsentrasi 90\% dengan rata-rata zona hambat $11,5 \mathrm{~mm}$ dengan menggunakan metode difusi. Penelitian Rasyid S.R, et.al., (2020) bahkan menyatakan hambatan Staphylococcus aureus pada konsentrasi $100 \%$ dengan zona hambat $8 \mathrm{~mm}$ pada metode yang sama. Penelitian lain pada bakteri yang sama tetapi menggunakan air perasan jeruk purut memperoleh zona hambat lebih tinggi yaitu $17.25 \mathrm{~mm}$ pada konsentrasi $50 \%$ (Kusumawardhani, N., 2020). Perbedaan konsentrasi tersebut dapat disebabkan oleh kandungan dan kadar senyawa metabolit sekunder yang terdapat disetiap umur dalam daun kirinyuh yang digunakan berperan sebagai antibakteri sehingga dapat menyebabkan perbedaan efektivitas penghambatan yang dihasilkan.

Penelitian lain tentang daya hambat terhadap Staphylococcus aureus tetapi pada ekstrak yang berbeda memperoleh hasil yang bervariasi. Pada ekstrak serbuk bawang putih KBM terjadi pada konsentrasi 50\% (Agnina L.A, 2020), kayu manis pada konsentrasi $40 \%$ (Huda, N., 2019). Hasil penelitian ini menunjukkan KBM pada Salmonella typhi dikonsentrasi $40 \%$, sedangkan pada penelitian lain dengan menggunakan ekstrak rosella hasil KBM berada pada konsentrasi yang lebih tinggi yaitu 70\% (Sutiany, A., 2019). Metabolit sekunder yang terkandung dalam tumbuhan yang dimanfaatkan sebagai antibakteri mempunyai mekanisme kerja yang berbeda-beda dalam menghambat pertumbuhan bakteri. Adanya mekanisme kerja yang sinergis dari senyawa metabolit sekunder akan semakin efektif dalam menghambat pertumbuhan bakteri.

Menurut Priono efektivitas ekstrak etanol daun kirinyuh. sebagai antibakteri diduga berhubungan dengan kandungan senyawa metabolit sekunder yang berada dalam ekstrak. Hal ini sesuai dengan hasil uji fitokimia 
daun kirinyuh yang memiliki beberapa kandungan senyawa metabolit sekunder yang dapat berfungsi sebagai antibakteri diantaranya alkaloid, flavonoid, saponin, steroid, triterpenoid dan tanin. Kerusakan yang ditimbulkan senyawa antibakteri tersebut dapat bersifat bakterisidal (membunuh bakteri) dan bakteristatik (menghentikan sementara pertumbuhan bakteri).

Menurut Sirinthipaporn (2017) ekstrak etanol daun kirinyuh mengandung flavonoid (rutin) dengan kadar yang tinggi. Flavonoid merupakan senyawa yang berfungsi sebagai antimikroba dengan cara membentuk senyawa kompleks terhadap protein ekstraseluler yang mengganggu integritas membran dan dinding sel. Menurut Nurhanafi, 2012, Flavonoid juga bersifat desinfektan dan bakteriostatik yang bekerja dengan cara mendenaturasi protein yang dapat menyebabkan aktivitas metabolisme sel bakteri berhenti.

Ngozi dkk (2009) menyatakan bahwa daun kirinyuh mengandung kadar saponin yang tinggi dan mengandung alkaloid dari golongan auron, chalcon, flavon dan flavonol serta kandungan tannin yang sedang. Mekanisme saponin sebagai antibakteri adalah dengan cara merusak porin yang merupakan pintu keluar masuknya senyawa akan mengurangi permeabilitas dinding sel bakteri yang akan mengakibatkan sel bakteri akan kekurangan nutrisi, sehingga pertumbuhan bakteri terhambat atau mati. Kandungan alkaloid dalam ekstrak etanol daun kirinyuh mempunyai kemampuan antibakteri karena memiliki gugus aromatik kuartener yang mampu mengganggu integritas komponen penyusun peptidoglikan pada sel bakteri (Rachmawati, 2009).

Selain itu, senyawa yang terdapat dalam daun kirinyuh yang juga berfungsi sebagai antibakteri yaitu tanin. Tanin dapat menghambat sintesis kitin dalam pembentukan dinding sel dan merusak membran sel sehingga pertumbuhan bakteri terhambat. Sedangkan triterpenoid mempunyai mekanisme antibakteri dengan cara pengrusakan membran sel bakteri (Ajizah, 2004). Daun kirinyuh juga mengandung 56 macam minyak esensial, diantaranya $\alpha$-Pinene $42,2 \%$, $\beta$-Pinene $10,6 \%$, dan Germacrene D 9,7\% (Priono, 2016)

Berdasarkan hasil penelitian ini maka dapat dinyatakan bahwa ekstrak etanol daun kirinyuh memiliki efektivitas terhadap pertumbuhan Salmonella typhi dan Staphylococcus aureus. Maka dari itu sebaiknya dilakukan uji lanjutan pada hewan percobaan dan uji klinis agar menjadi obat yang dapat digunakan pada masyarakat luas.

\section{SIMPULAN}

Konsentrasi Hambat Minimal (KHM) ekstrak etanol daun kirinyuh terhadap Salmonella typhi: 20\% dan Staphylococcus aureus: $20 \%$. Konsentrasi Bunuh Minimal (KBM) ekstrak etanol daun kirinyuh terhadap Salmonella typhi: $40 \%$ dan Staphylococcus aureus: 40\%. Ekstrak etanol daun kirinyuh mempunyai daya hambat terhadap pertumbuhan Salmonella typhi dan Staphylococcus 
aureus secara intitro sehingga berpotensi menjadi obat herbal terhadap infeksi bakteri namun memerlukan penelitian lebih lanjut untuk mengetahui pengaruhnya secara in vivo.

\section{UCAPAN TERIMAKASIH}

Penulis mengucapkan terimakasih kepada pihak yang telah membantu terlaksananya penelitian ini, khususnya kepada Poltekkes Kemenkes Banjarmasin, Unit Penelitian Poltekkes, dan Laboratorium di Kampus Teknologi Laboratorium Medik yang telah memfasilitasi penelitian ini.

\section{DAFTAR PUSTAKA}

Agnina Listya Anggraini, Ratih Dewi Dwiyanti, Anny Thuraidah, 2020. Garlic Extract (Allium sativum L.) Effectively Inhibits Staphylococcus aureus and Escherichia coli by Invitro Test. Tropical Health and Medical Research. 2(2); 61-68. https://doi.org/10.35916/thmr.v0i0 .22

Ajizah A, 2004. Sensitivitas Salmonella typhimurium terhadap Ekstrak Daun Psidium Guajava L. Jurnal Bioscientiae, 1 (1): 8-31.

Fahani, A., Dwiyanti, RD., Muhlisin. A., 2019. Contamination of Bacillus cereus in Elementary School Snack Food. Tropical Health and Medical Research. 1(2): 56-61. https://doi.org/10.35916/thmr.v1i2 .10

Hidayatullah ME, 2018. Potensi Ekstrak Etanol Tumbuhan Kirinyuh (Chromolaena odorata) sebagai
Senyawa Anti-Bakteri, University Research Colloqium.

Huda, N., Dwiyanti, RD., Thuraidah. A., 2019. Effectiveness of Cinnamon (Cinnamomum burmannii) Ethanol Extract Against Staphylococcus aureus Growth. Tropical Health and Medical Research. 1(2): 39-43. https://doi.org/10.35916/thmr.v1i2 6

Kusumawardhani, N., Thuraidah, A., Nurlailah., 2020. Citrus hystrix D.C Fluid Inhibits The Growth of Staphylococcus aureus. Tropical Health and Medical Research. 2(1); 34-38

Laia H, Yusliana, Daeli P, Sarwendah, Chiumam L, 2019. Uji Antibakteri Air Perasan Daging Buah Nanas (Ananas Comosus (L) Merr) terhadap Bakteri Staphylococcus cureus. Jurnal Kedokteran dan Kesehatan, 1 (2). Mustika Sari, P., Lutpiatina, L., Muhlisin. $\quad$ A., 2019. Staphylococcus aureus in Traditional Coconut milk Drinks. Tropical Health and Medical Research. 1(1): 33-38. https://doi.org/10.35916/thmr.v1i1 .1

Ngozi, I.M., Jude, I.C., dan Catherine, I.C. 2009. CheKHMal Profile of ChromolaenaL. (King and Robinson) Leaves. Pakistan Journal of Nutrition, 8(5): 521524.

Nurhanafi F, 2012. Perbandingan Potensi Antimikroba Ekstrak nHeksana Daun Kelor (Moringa oleifera) dengan Kulit Biji 
(Pericarp) Jambu Mete (Anacardium occidentale) terhadap Bakteri Pseudomonas aeruginosa secara in vitro, Skripsi, Program Kedokteran Hewan Universitas Brawijaya.

Priono A, Yanti N, Lili D, 2016. Perbandingan Efektivitas Antibakteri Ekstrak Etanol Daun Kelor (Moringaoleifera lamck.) dan Ekstrak Daun Chromolaena odorata L.. Jurnal Ampibi 1 (2) : 1-6.

Rahayu RS, 2017. Aktivitas Ekstrak Etanol Daun kirinyuh (Chromolaena odorata) sebagai Antibakteri terhadap Escherichia coli, Staphylococcus aureus dan Pseudomonas aeruginosa, Skripsi. Universitas Negeri Medan.

Rasyid, S. A., Sugireng, Surya, R. A., Sanatang, Rosdarni, \& Natalia, W. O. R. (2020). The antibacterial activity of Tembelekan leaf (Lantana camara L.) and Kopasanda leaf (Chromolaena odorata L.) extracts against Staphylococcus aureus. Infectious Disease Reports, 12(1s). https://doi.org/10.4081/idr.2020.8 734

Rifa'i, A., Muhlisin, A., Lutpiatina L., 2019. Erythrocyte Morphology of Tuberculosis Patients. Tropical Health and Medical Research. 1(1): 10-18. https://doi.org/10.35916/thmr.v1i1 .3

Rostinawati T, Suryana S, Fajrin M, Nugrahani H, 2018. Aktivitas Antibakteri Ekstrak Etanol Daun Kelakai (Stenochlaena palustris
(Burm.F) Bedd) Terhadap

Salmonella typhi dan Staphylococcus aureus dengan Metode Difusi Agar CLSI M02A11. Jurnal Pharmauho 3 (1) : 15.

Sirinthipaporn, Anushika, Wannee J, 2017. Wound Healing Property Review Of Siam Weed, Chromolaena Odorata. Jurnal Pharmacognosy Review. 11(21): 35-38.

Sutiany, A., Dwiyanti, RD., Oktiyani. N., 2019. Inhibition Strength of Rosella (Hibiscus sabdariffa L.) Boiled Water on Salmonella typhi in vitro. Tropical Health and Medical Research. 1(2): 62-67. https://doi.org/10.35916/thmr.v1i2 .7

Tanu I, 2012. Farmakologi Dan Terapi, Edisi Kelima, Badan Penerbit FKUI, Jakarta.

Vaisakh M, Pandey, 2012. The Invasive Weed With Healing Properties: A review On Chromolaena Odorata. Departemen Of Pharmaceutical Science. 3 (1): 80-83.

WHO, 2018. Typhoid vaccines: WHO position paper. Weekly Epidemiological Record, 93 (No. 33) : 153-172

Wulandari MA, 2014. Potensi Antibakteri Dan Bioautografi Ekstrak Etanol Daun Bintaro (Carbera odollam gaertn) Terhadap Salmonella typhi Dan Staphylococcus aureus. Skripsi thesis. Fakultas Farmasi Universitas Muhammadiyah Surakarta Surakarta. 
Yusliana, Sarwendah, Heronimus, C, Pieter J, Linda, C, 2019. Uji Daya Hambat Antibakteri Air Perasan Daging Buah Nanas (Ananas comosus (L) Merr Var. Queen) Terhadap Salmonella typhi. Jurnal Scientia, 8 (1).

Yutika M., Rolan R., Adam, 2015. Aktivitas Antibakteri Daun kirinyuh (Chromolaena Odorata (L.) R.M.King \& H.Rob.) Terhadap Bakteri Gangren. Prosiding Seminar Nasional Kefarmasian Ke-2 Samarinda. 7581. 